\title{
Synthesis of Monoacylglycerol Rich in Polyunsaturated Fatty Acids from Tuna Oil with Immobilized Lipase AK
}

\author{
Pawongrat, Ratchapol; Xu, Xuebing; H-Kittikun, Aran
}

Published in:

Food Chemistry

Link to article, DOI:

10.1016/j.foodchem.2006.11.036

Publication date:

2007

Link back to DTU Orbit

Citation (APA):

Pawongrat, R., Xu, X., \& H-Kittikun, A. (2007). Synthesis of Monoacylglycerol Rich in Polyunsaturated Fatty Acids from Tuna Oil with Immobilized Lipase AK. Food Chemistry, 104(1), 251-258.

https://doi.org/10.1016/j.foodchem.2006.11.036

\section{General rights}

Copyright and moral rights for the publications made accessible in the public portal are retained by the authors and/or other copyright owners and it is a condition of accessing publications that users recognise and abide by the legal requirements associated with these rights.

- Users may download and print one copy of any publication from the public portal for the purpose of private study or research.

- You may not further distribute the material or use it for any profit-making activity or commercial gain

- You may freely distribute the URL identifying the publication in the public portal

If you believe that this document breaches copyright please contact us providing details, and we will remove access to the work immediately and investigate your claim. 
1 Synthesis of Monoacylglycerol Rich in Polyunsaturated Fatty Acids from Tuna

2 Oil with Immobilized Lipase AK

3

4 Ratchapol Pawongrat ${ }^{a}$, Xuebing $\mathrm{Xu}^{b}$ and Aran H-Kittikun ${ }^{a^{*}}$

$5 \quad{ }^{a}$ Department of Industrial Biotechnology, Faculty of Agro-Industry, Prince of Songkla

6 University, Hat Yai 90112, Thailand.

7 bioCentrum-DTU, Technical University of Denmark, Building 227, DK-2800 Kgs,

8 Lyngby, Denmark.

9

10

11

12

13

14

15

* Corresponding author. Tel.: +66 7428-6363; fax: +66 7421-2889

16 E-mail: aranxyz@yahoo.com

17

18 
1

2

3

5

\section{Abstract}

The aim of this study is to produce monoacylglycerols (MAG) rich in polyunsaturated fatty acids (PUFA), especially eicosapentaenoic acid (EPA) and docosahexaenoic acid (DHA), by glycerolysis of tuna oil with Lipase AK from Pseudomonas fluorescence immobilized on Accurel EP-100 (IM-AK). tert-Butyl methyl ether (MTBE) was the most suitable organic solvent after screening a list of different solvents and their mixtures. The optimum condition for MAG production was found to be $10 \% \mathrm{w} / \mathrm{v}$ of tuna oil in MTBE, the mole ratio of glycerol to tuna oil 3:1, water added $4 \mathrm{wt} \%$ in glycerol, and the amount of IM-AK $30 \mathrm{wt} \%$ based on tuna oil. The temperature was controlled at $45^{\circ} \mathrm{C}$. Under these conditions with $24 \mathrm{~h}$ reaction, the yield of MAG was $24.6 \%$ but containing $56.0 \mathrm{wt} \%$ PUFA (EPA and DHA). Stability of the IM-AK was also studied. The hydrolytic activity of the enzyme remained 88 and $80 \%$ of initial activity after incubated in MTBE for 24 h at 4 and 45 ${ }^{\circ} \mathrm{C}$, respectively. The $K_{\mathrm{m}}$ and $V_{\max }$ values of the lipase-catalyzed glycerolysis of tuna oil in MTBE were found to be $19.47 \mathrm{mM}$ and 2.71mgMAG/min, respectively, for IMAK.

Key words: Monoacylglycerols, glycerolysis, polyunsaturated fatty acids (PUFA), Immobilized lipase, Lipase AK, tuna oil

(1)

(1)




\section{Introduction}

Tuna oil is currently one of the major sources of polyunsaturated fatty acids (PUFA), especially, eicosapentaenoic acid (EPA) and docosahexaenoic acid (DHA). The oil contains approximately 5.7\% EPA and 18.8\% DHA which are distributed in mixed triacylglycerols (TAG) with ordinary fatty acids (Wongsakul, Prasertsan, Bornscheuer and H-Kittikun, 2003). PUFA have received much attention in recent years because of the health benefits including reduced risk of coronary disease, prevention of certain cancers, and improved immune functions (Narayan, Miyashita and Hosakawa, 2006; Ruxton, Reed, Simpson and Millington, 2004).

Monoacylglycerols (MAG) or mixtures with diacylglycerols (DAG) account for approximately $75 \%$ of the emulsifier production and have various applications in different fields (Bornscheuer, 1995; Damstrup, Jensen, Sparsø, Kiil, Jensen and Xu, 2005). MAG are nonionic emulsifiers widely used in bakery products, margarines, diary products, confectionary because of their emulsifying, stabilizing and conditioning properties. Moreover, MAG are also used in pharmaceutical as binders in tablets and as emollients for transdermal, slow-release drugs. Due to the worldwide importance of MAG and their derivatives as surface active additives in a wide range of foods, considerable attention has recently been paid to improve the synthesis of MAG. They are also of great interest in synthetic organic chemistry where they are utilized as synthetic intermediates and as chiral building blocks (Monteiro, Nascimento and Ninow, 2003).

Chemically, MAG can be synthesized at high temperatures using several metallic catalysts. Commercial MAG are widely manufactured by glycerolysis of fats and oils. The glycerolysis reaction is accelerated by the use of inorganic alkaline catalysis, such as $\mathrm{NaOH}$ or $\mathrm{Ca}(\mathrm{OH})_{2}$ at $220-260^{\circ} \mathrm{C}$. However, this leads to a number 
1 of unwanted side products and the reaction occurs in a random manner so that

2 extensive purification of products is required (McNeill \& Yamane, 1991; Yang,

3 Rebsdorf, Engelrud and Xu, 2005; Damstrup et al., 2005). Furthermore, the high-

4 temperature chemical process is not suitable for the production of heat-sensitive MAG

5 containing PUFA, in particular from fish oils. Production of heat-sensitive MAG is,

6 however, of great commercial interest owing to their nutritive value, which could be

7 applied in foods and pharmaceuticals (Damstrup et al., 2005; Kaewthong \& $\mathrm{H}$ -

$8 \quad$ Kittikun, 2005; Yang et al., 2005).

Due to disadvantages of the conventional process, the use of enzymes as catalysts, thus, seems to be a potential as well as imperative alternative for practical considerations. The much lower temperature used (less than $80^{\circ} \mathrm{C}$ ) improves product quality and makes production of heat-sensitive MAG feasible. Lipases have shown a good stability and activity in hydrophobic solvents for MAG synthesis by glycerolysis (Damstrup et al., 2005; Kristensen, Xu and Mu, 2005).

Several studies have dealt with the synthesis of MAG enriched in PUFA such as alcoholysis of triacylglycerols with ethanol using a 1,3-regiospecific lipase or glycerolysis of fish oil using an immobilized lipase (Sakiyama, Toshimi, Tanaka, Osaki and Nakanishi, 2001; Wongsakul et al., 2003; Yang et al., 2005).

Glycerolysis of triacylglycerols (TAG) with lipase in the liquid phase typically yields only 30-50\% MAG (Bornscheuer, 1995; Kaewthong \& H-Kittikun, 2005). Some authors improved their systems by carrying out the reaction first in a liquid state, but reducing the temperature to crystallize the formed MAG. This led to a shift in the reaction equilibrium so that yields increased to 70-90\%. However, continuous production of MAG by this method was impossible (Kaewthong \& H-kittikun, 2005). For the bioconversion of various lipophilic or water-insoluble compounds, it is 
1 essential to introduce organic solvents into reaction systems to improve the solubility

2 of these reactants. Furthermore, use of suitable solvents system will result in more

3 homogeneous system and enhance the conversion of substrate, the reaction rate, and

4 the production distribution in favor of MAG formation as well as PUFA content in 5 MAG.

6 In this work, under the decision of enzymatic glycerolysis with tuna oil as 7 substrate, a list of solvents were first evaluated for the synthesis of MAG. Optimal 8 reaction parameters were investigated in order to obtain MAG in high yields as well 9 as with high PUFA (defined as EPA and DHA) content. Major focus was given to the enrichment of EPA and DHA in the MAG fraction.

\section{Materials and methods}

Materials

Crude tuna oil, with water content of $4.7 \%$, was provided from Chotiwat Industrial Co. Ltd (Hat Yai, Thailand). The crude oil was obtained from skipjack tuna heads by a conventional pressing method. The refined oil was achieved through degumming, neutralization, bleaching, and deodorizing. Lipase AK, from Pseudomonas fluorescens, with water content of 0.04\%, was a gift from Amano (Nagoya, Japan). Microporous polypropylene powder, Accurel EP-100 (particle size $<400 \mu \mathrm{m}$ ) was a gift from Akzo Nobel (Obermburg, Germany). All other chemicals and solvents used were of reagent grade or analytical grade. Hydrolytic activity of lipases Hydrolytic activity of the immobilized lipase was determined by the modified cupric acetate method of Lee and Rhee (1993). One unit of hydrolytic activity was defined as 
1 the amount of enzyme which liberates $1 \mu \mathrm{mol}$ equivalent of palmitic acid from palm

2 olein in $1 \mathrm{~min}$ at $30^{\circ} \mathrm{C}$.

3 Preparation of immobilized lipase

4 Accurel EP-100 (10 g) was added to $100 \mathrm{ml}$ of $0.1 \mathrm{M}$ phosphate buffer ( $\mathrm{pH}$ 7)

5 containing app. $100 \mathrm{U} / \mathrm{ml}$ Lipase $\mathrm{AK}$ and the reaction mixture was stirred with a

6 magnetic bar at $100 \mathrm{rpm}$ for $30 \mathrm{~min}$. Afterward, $100 \mathrm{ml}$ of $0.1 \mathrm{M}$ phosphate buffer

$7 \quad(\mathrm{pH}$ 7) was added and the suspension was filtered through a Buchner funnel by

8 vacuum. The immobilized enzyme was washed with $100 \mathrm{ml}$ of the buffer to remove

9 soluble enzyme and dried in a vacuum desiccator. The immobilized Lipase AK on

10 Accurel EP-100 (IM-AK) was stored at $4^{\circ} \mathrm{C}$ for further uses.

11 Glycerolysis reaction

12 The initial glycerolysis experiments were carried out in a batch system. The reaction 13 mixture consisted of IM-AK (water content 3.0\%) 0.6 g, glycerol (99.5\%, water 14 content $0.2 \%) 1.78 \mathrm{~g}$, and $20 \mathrm{ml}$ of $30 \%(\mathrm{w} / \mathrm{v})$ of tuna oil in organic solvents. Extra 4 $15 \mathrm{wt} \%$ water based on the glycerol was added directly to glycerol. The temperature was 16 controlled at $45^{\circ} \mathrm{C}$. The reaction was mixed on the shaker at $300 \mathrm{rpm}$. Samples of the 17 reaction mixture were centrifuged to remove IM-AK before analysis.

18 Analysis of glycerides by TLC-FID

19 The components of oil phase were analyzed with a thin-layer chromatography and 20 flame ionization detector (TLC/FID) (IATROSCAN MK5, Iatron Laboratories Inc. 21 (Tokyo, Japan) for the content of TAG, 1,2(2,3)-DAG, 1,3-DAG, MAG and free fatty 22 acids (FFA) (Kaewthong \& H-kittikun, 2005). The sample diluted in 23 chloroform/methanol $(2: 1 \mathrm{v} / \mathrm{v})$ was spotted onto the chromarod and developed for 35 $24 \mathrm{~min}$ in a mixture of benzene/chloroform/acetic acid (50:20:0.7 v/v/v) as developing 25 solvent. After development and drying, the rods were subjected to scanning with FID. 
1 Standards were used to identify the peaks. The peak areas were normalized and used

2 for evaluation of the reactions.

3 Analysis of fatty acids compositions

4 The fatty acid compositions of glyceride species were determined by converting into

5 fatty acid methyl esters (FAME) followed by GC analysis. After evaporating

6 excessive solvent of the sample, the mixture was applied to the normal TLC-plate

7 with silica gel and developed in benzene/chloroform/acetic acid (50:20:0.7 v/v/v).

8 After drying, the MAG band was scraped off and methylated with $0.5 \% \mathrm{NaOH}$ in

9 methanol $(1000 \mu \mathrm{l})$ for $10 \mathrm{~min}$ at $60^{\circ} \mathrm{C}$. The methyl esters were extracted with $n$ 10 hexane (300 $\mu$ l) for $1 \mathrm{~min}$. The $n$-hexane layer was washed with $200 \mu$ l distilled water 11 and dried over anhydrous sodium sulfate. Analysis was carried out with a Perkin12 Elmer Autosystem XL-GC gas chromatograph (Perkin-Elmer, Norwalk, CT) on a 13 FFFAP column (PERMABOND-FFFAP DF-0.25, 25m $\times 0.25 \mathrm{~mm}$ i.d., MACHEREY14 NAGEL, Germany). The carrier gas used was helium at a flow rate of $0.5 \mathrm{ml} / \mathrm{min}$ (15 15 psi) and operated in a spit mode with a spit ratio of 50:1. The temperature was started 16 from $150^{\circ} \mathrm{C}$ for $0.50 \mathrm{~min}$ and increased at the rate of $4^{\circ} \mathrm{C} / \mathrm{min}$ to $170{ }^{\circ} \mathrm{C}$, followed 17 with the rate of $5^{\circ} \mathrm{C} / \mathrm{min}$ to $195^{\circ} \mathrm{C}$, and further with the rate of $10^{\circ} \mathrm{C} / \mathrm{min}$ to $215^{\circ} \mathrm{C}$. the 18 temperature was kept at $215^{\circ} \mathrm{C}$ for 14 min. Injector and detector temperatures were $19250^{\circ} \mathrm{C}$ (Joseph \& Ackman, 1992). Response factors were determined using a standard 20 mixture of fatty acid methyl esters.

21 Regiospecific analysis

22 The regiospecific analysis of tuna oil was conducted by Grignard degradation with 23 allylmagnesium bromide followed by isolation, methylation, and GC analysis 24 (Soumanou, Bornscheuer and Schmid, 1998; Wongsakul et al., 2003). Karl Fischer water content determination 
1 The water content in the tuna oil, the immobilized lipase, and glycerol as well as in

2 the solvents was determined by Karl Fischer method (720 KFS Titrino, Switzerland,

3 using HYDRANAL titrant and solvents) (Xu, Fomuso and Akoh, 2000).

$4 \quad$ Statistical analysis

5 The SPSS program was used for data analysis (SPSS, 1989-2001). Analysis of

6 variance and t-test were used to evaluate the significance and difference of data.

$7 \quad$ Values were considered significant at $P<0.05$ level.

8

\section{Results and discussions}

\section{Screening of solvents for the enzymatic glycerolysis of tuna oil.}

To select the most suitable solvent for the glycerolysis reaction system, the effect of organic solvents on the catalytic activity of the lipase was examined. The glycerolysis of tuna oil with IM-AK as biocatalyst was carried out in acetone, hexane, isooctane, tert-butyl methyl ether (MTBE) and their combinations. The results are shown in Fig. 1. It was found that MTBE gave the highest yield of MAG at $20.4 \mathrm{wt} \%$ with yield of PUFA (EPA and DHA) about 14.8 wt\%. Previously, Kaewthong and HKittikun (2005) used the combination of acetone/isooctane mixture (3:1, v/v) as solvent for glycerolysis of palm olein. Wongsakul et al. (2003) used acetone as organic solvent for alcoholysis of tuna oil by Lipase PS-C. Moreover, Chang and Rhee (1991) used isooctane as organic solvent for continuous glycerolysis of olive oil in CSTR. Therefore, the selection of solvent seems affected by many different issues. As information collected so far, it is strongly dependent on the selection of lipases. Other issues such as oil type, reactor selection, and reaction mechanism might have effect as well. As to this study, we decided to use MTBE for further study. 


\section{Effect of water content}

Water content is recognized as an important factor in transesterification reactions. A certain amount of water is necessary to preserve the catalytically active conformation of the enzyme and to allow the formation of an acyl-enzyme complex. In contrast, excessive water causes acyl migration lead to decrease in MAG yield (Wongsakul et al., 2003). Therefore, optimal water content is the foremost important factor that should be sorted out in the quite hydrophilic solvent. Initial water content of the glycerol in the range of 4-12 wt\% was studied. The results are shown in Fig 2. The highest yield of MAG of 20.7 wt\% contained 15.7 wt\% PUFA was obtained when $4 \%$ the water was added in glycerol. When more than $4 \%$ water was added, the yield of MAG dropped gradually. This may be due to hydrolysis. Yamane, Kang, Kawahara and Koizumi (1994) found that FFA content at equilibrium depended on the water concentration in the glycerol phase. This can eventually lead to the decrease of MAG yields as early mentioned.

\section{Effect of substrate concentration in MTBE}

In a solvent system, the concentration of substrate will eventually affect the reaction rate based on Michaelis-Menten kinetics even though solvent can help create a homogeneous system. In order to select an efficient initial substrate (tuna oil) concentration for glycerolysis, the effect of tuna oil concentration was investigated. The results are shown in Fig. 3. The MAG yield increased with increasing the concentration of tuna oil as well as PUFA content in MAG increased when tuna oil concentration was increased. At the concentration of $10 \% \mathrm{w} / \mathrm{v}$ tuna oil in MTBE with the mole ratio of glycerol to tuna oil about 3:1, the best yield of MAG at $22.1 \mathrm{wt} \%$ with PUFA content about 38.5 wt $\%$ was obtained after 24 h incubation. When the concentration of tuna oil was lower than $10 \% \mathrm{w} / \mathrm{v}$, the yield of MAG was decreased. 
1 Solvent plays multiple roles and has more than one function in the system. It is first to make a homogeneous system and increase mass transfer by reducing the viscosity of the system. One the other hand, solvent may increase inhibition to the lipase since it deprives off water from the lipase structure. Certainly addition of solvent decreases the amount of available substrate at the interface between the solvent and glycerol and hence decreases the MAG yield. The amount of glycerol also plays a role in reactions and the system. Glycerol in the mixture would create difficulty for the reaction system if without solvent. On the other hand, Yang and Rhee (1991) suggested that glycerol could act as an effective stabilizer against thermal and solvent denaturation. However, Bornscheuer and Yamane (1994) showed that the optimum mole ratio of glycerol to palm olein for MAG production in the solid-phase system was 2.7:1 where at lower glycerol to TAG mole ratio (1:2), the main product of glycerolysis was diacylglycerols. Therefore, the amount of glycerol affected also the reaction equilibrium. In the present study, $10 \%$ w/v of tuna oil with ca. 3 fold glycerol addition in moles gave the optimal system of the glycerolysis reaction.

\section{Effect of IM-AK loading}

The effect of IM-AK loading on MAG production was determined. The results are shown in Fig 4. When increasing the amount of IM-AK in the reaction mixture, the MAG production was also increased. However, no benefit came from increasing IM-AK above $30 \mathrm{wt} \%$ of tuna oil. Therefore, the amount of IM-AK $30 \mathrm{wt} \%$ of tuna oil was used for further study.

\section{Effect of temperature}

Temperature plays two roles in the reaction system. Firstly, higher temperature can reduce the viscosity as well as improve the substrate diffusion or its solubility. Secondly, enzymes usually have a temperature optimum. Therefore, an optimal 
temperature should be selected in terms of the overall performance of the reaction. The effect of temperature $\left(30-50^{\circ} \mathrm{C}\right)$ on MAG production from tuna oil was studied. When temperature was controlled in $30-45^{\circ} \mathrm{C}$, the MAG production increased with increasing temperature (data not shown). This result was a consequence of the increase in the reaction rate. In contrast, when increasing the temperature from 45 to $55^{\circ} \mathrm{C}$ the yield of MAG was decreased. The temperature of $45^{\circ} \mathrm{C}$ was considered an optimal temperature for the reaction system.

\section{Stability of IM-AK in MTBE mixture}

Stability of IM-AK in MTBE was studied at 4 and $45^{\circ} \mathrm{C}$. The results show that more than 88 and $80 \%$ of hydrolytic activity remained after incubation for $24 \mathrm{~h}$, respectively (data not shown). However, Fukui, Kawamoto, Sonomto and Tanaka (1990) found that benzene was better for lipase stability while gave a moderate result for lipase activity. Kang and Rhee (1989) suggested that the immobilized lipase activity in a reverse-phase system decreased as the polarity of solvent increases. Kwon, Han and Rhee (1995) reported that the enzyme was stabilized by the substrate in a two-phase reaction system (isooctane-water); the half-life of the enzyme was $10 \mathrm{~h}$ without the substrate and $20 \mathrm{~h}$ with $30 \%$ olive oil at $30{ }^{\circ} \mathrm{C}$. Stability is a very complicated issue for many lipases. It not only relates to the characteristics of a lipase but also relates to the reaction system selected. More work is needed to improve the stability of the lipase used.

\section{MAG production under optimal conditions}

The optimal conditions for MAG production were decided as tuna oil concentration of $10 \% \mathrm{w} / \mathrm{v}$ in MTBE, the mole ratio of glycerol to tuna oil about 3:1, water content in glycerol with 4 wt $\%$ and using IM-AK 30 wt $\%$ of tuna oil. The temperature was controlled at $45^{\circ} \mathrm{C}$. The reaction time course is given in Fig. 5. The 
1 yield of MAG was $24.5 \mathrm{wt} \%$ and PUFA (EPA and DHA) content was $56.0 \mathrm{wt} \%$ after

224 h incubation.

The reaction products were separated by TLC. The fatty acid profiles of each band (glyceride species) were determined by GC (Table 1). As shown, monodocosahexylglycerol and monooleylglycerol were the predominant MAG in the products.

\section{Kinetics of the glycerolysis using both Lipase AK and IM-AK}

The kinetic constants ( $K_{\mathrm{m}}$ and $\left.V_{\max }\right)$ for glycerolysis of tuna oil with the nonimmobilized Lipase AK as well as its immobilized form (IM-AK) were determined in MTBE by measuring initial reaction rates with varying amount of tuna oil (50$500 \mathrm{mM}$ ). The results are shown in Fig 7. The values of the kinetic constants were obtained from Lineweaver-Burk plot. $K_{\mathrm{m}}$ and $V_{\max }$ of the original Lipase AK were $39.26 \mathrm{mM}$ and $11.38 \mathrm{mgMAG} / \mathrm{min}$, respectively; while $K_{\mathrm{m}}$ and $V_{\max }$ of IM-AK were 19.47 $\mathrm{mM}$ and $2.71 \mathrm{mgMAG} / \mathrm{min}$, respectively. IM-AK had smaller $K_{\mathrm{m}}$ and $V_{\max }$ values than its original form, meaning the catalytic capacity of the immobilized form was reduced. The potential allowed substrate concentration is also reduced. A similar result was obtained in hydrolysis of olive oil by Candida rugosa lipase (Montero, Blanco, Virto, Landeta, Agud and Solozabal, 1993). In general, the immobilization of biocatalysts can lead to an activity reduction. It can also cause diffusional limitation of substrates in the immobilized biocatalyst system.

\section{Conclusions}

Glycerolysis of tuna oil was investigated to produce MAG rich in PUFA using immobilized Lipase AK. The optimum conditions for MAG production were found to be $10 \% \mathrm{w} / \mathrm{v}$ of tuna oil in MTBE, glycerol to tuna oil ca. 3:1 mol/mol, water added in 
1 glycerol was $4 \mathrm{wt} \%$ and the amount of IM-AK used was $30 \mathrm{wt} \%$ of tuna oil. The

2 temperature was controlled at $45^{\circ} \mathrm{C}$. Under these conditions, the yield of $24.6 \mathrm{wt} \%$

3 containing of $56.0 \mathrm{wt} \%$ PUFA (EPA and DHA) was obtained at $24 \mathrm{~h}$. MAG were

4 produced in good yield with high content of PUFA, especially, EPA and DHA. Thus,

5 a suitable product or starting material for synthesis of structured triglycerides can be 6 obtained.

7

8 Acknowledgments

9 The research support by the Royal Golden Jubilee Program (RGJ, Thailand) is 10 gratefully acknowledged. The authors would like to thank Chotiwat Industrial Co. Ltd. (Hat Yai, Thailand) for providing crude tuna oil and Amano (Nagoya, Japan) for lipases, as well as, Akzo Nobel for Accurel EP-100. 


\section{References}

Bornscheuer, U.T., \& Yamane, T. (1994). Activity and stability of lipase in the solidphase glycerolysis of triolein. Enzyme and Microbial Technology, 16, 864-869.

Bornscheuer, U.T. (1995). Lipase-catalyzed synthesis of monoacylglycerols. Enzyme and Microbial Technology, 17, 578-586.

Chang, P.S., \& Rhee, J.S. (1991). Continuous glycerolysis of olive oil by Chromobacterium viscosum lipase immobilized on liposome reversed micelles. Biotechnology and Bioengineering, 38, 1159-1165.

Damstrup, M.L., Jensen, T., Sparsø, F.V., Kiil, S.Z., Jensen, A.D., \& Xu, X. (2005). Solvent optimization for efficient enzymatic monoacylglycerol production based on a glycerolysis reaction. Journal of the American Oil Chemists' Society, 82, 559-564.

Fukui, T., Kawamoto, T., Sonomoto, K., \& Tanaka. (1990). Long-term continuous production of optically active 2-(4-chlorophenoxy) propanoic acid by yeast lipase in an organic solvent system. Applied Microbiology and Biotechnology, 34, 330-334.

Joseph, J.D., \& Ackman. (1992). Capillary column gas chromatographic method for analysis of encapsulated fish oil and fish oil ethyl ester: collaborative study. Journal of AOAC International, 75, 488-506.

Kaewthong, W., \& H-Kittikun, A. (2004). Glycerolysis of palm olein by immobilized lipase PS in organic solvents. Enzyme and Microbial Technology, 35, 218-222.

Kang, S.T., \& Rhee, J.S. (1989). Characteristics of immobilized lipase-catalyzed hydrolysis of olive oil of high concentrate in reverse phase system. Biotechnology and Bioengineering, 33, 1469-1476. 
1 Kristensen, J.B., Xu, X., \& Mu, H. (2005). Diacylglycerol synthesis by enzymatic glycerolysis: screening of commercially available lipases. Journal of the American Oil Chemists’ Society, 82, 329-334.

Kwon, S.J., Han, J.J., \& Rhee, J.S. (1995). Production and is situ separation of monoor diacylglycerol catalyzed by lipase in n-hexane. Enzyme and Microbial Technology, 17, 700-704.

Lee, S.Y., \& Rhee, J.S. (1993). Production and partial purification of lipase from Pseudomonas putida 3SK. Enzyme and Microbial Technology, 15, 617-623.

McNeill, G.P., \& Yamane, T. (1991). Further improvements in the yield of monoglycerides during enzymatic glycerolysis of fats and oils. Journal of the American Oil Chemists’ Society, 68, 6-10.

Montero, S., Blanco, A., Virto, M.D., Landeta, L. C., Agud, I., \& Solozabal, R. (1993). Immobilization of Candida rugosa lipase and some properties of the immobilized enzyme. Enzyme and Microbial Technology, 15, 239-247.

Monteiro, J.B., Nascimento, M.G., \& Ninow, J.L. (2003). Lipase-catalyzed synthesis of monoacylglycerol in a homogeneous system. Biotechnology Letters, 25, 641644.

Narayan, B., Miyashita, K., \& Hosakawa, M. (2006). Physiological effects of eicosapentaenoic acid (EPA) and docosahexaenoic acid (DHA)- A review. Food Reviews International, 22, 291-307.

Ruxton, C.H.S., Reed, S.C., Simpson, M.J.A., \& Millington, K.L. (2004). The health benefits of omega-3 polyunsaturated fatty acids: a review of the evidence. Journal of Human Nutrition and Dietetics, 17, 449-459. 
1 Soumanou, M.M., Bornscheuer, U.T., \& Schmid, R.D. (1998). Two-step enzymatic reaction for synthesis of pure structured triglycerides. Journal of the American Oil Chemists' Society, 75, 703-710.

SPSS (1989-2001). SPSS for window. Release 11.0.0 (19 Sept., 2001) standard version. SPSS Institute, Cary, NC.

Sakiyama, T., Yoshimi, T., Tanaka, A., Ozaki, S., \& Nakanishi, K. (2001). Analytical of monoglyceride synthesis reaction in a solvent-free two-phase system catalyzed by a monoacylglycerol lipase from Pseudomonas sp. LP7315. Biochemical Engineering and Sciences, 1, 88-90.

Wongsakul, S., Prasertsan, P., Bornscheuer, U.T., \& H-Kittikul, A. (2003). Synthesis of 2-monoglycerides by alcoholysis of palm oil and tuna oil using immobilized lipases. European Journal of Lipid Science and Technology, 105, 68-73.

Xu, X., Fomuso, L.B., \& Akoh, C.C. (2000). Modification of Menhaden oil by enzymatic acidolysis to produce structured lipid: optimization by response surface design kin packed bed reactor. Journal of the American Oil Chemists' Society, $77,171-176$.

Yamane, T., Kang, S.T., Kawahara, K., \& Koizumi, Y. (1994). High-yield diacylglycerol formation by solid-phase enzymatic glycerolysis of hydrogenated beef tallow. Journal of the American Oil Chemists’ Society, 71, 339-342.

Yang, T., Rebsdorf, M., Engelrud, U., \& Xu, X. (2005). Enzymatic production of monoacylglycerols containing polyunsaturated fatty acids through an efficient glycerolysis system. Journal of Agricultural and Food Chemistry, 53, 14751481. 
1 Table 1. Fatty acid compositions of species of tuna oil and reaction product after TLC

2 separation

\begin{tabular}{|c|c|c|c|c|c|c|c|c|c|c|}
\hline & \multirow[t]{2}{*}{ composition } & \multirow[t]{2}{*}{ wt \% } & \multicolumn{8}{|c|}{ Fatty acid composition (wt\%)* } \\
\hline & & & C14:0 & C16:0 & C16:1 & C18:0 & C18:1n-9 & C18:2n-6 & C20:5 & C22:6 \\
\hline \multirow[t]{4}{*}{ Fish oil } & TAG & 99.3 & 4.2 & 30.2 & 4.7 & 9.3 & 16.3 & 2.6 & 4.2 & 27.9 \\
\hline & MAG & 0.4 & 14.6 & 58.9 & 20.3 & - & 5.9 & - & - & - \\
\hline & FFA & 0.3 & 14.1 & 75.3 & 9.9 & - & - & - & - & - \\
\hline & $s n-2 * *$ & & 0.7 & - & 16.5 & 5.7 & 8.0 & 13.9 & 21.2 & 33.4 \\
\hline \multirow[t]{5}{*}{ Product } & TAG & 5.8 & 10.8 & 6.1 & 43.4 & - & 0.7 & 20.4 & 1.4 & 17.0 \\
\hline & 1,2-DAG & 18.9 & 3.1 & 26.5 & 5.1 & 5.8 & 6.2 & 18.4 & 9.2 & 25.3 \\
\hline & 1,3-DAG & 9.2 & 7.9 & 5.8 & 41.6 & 4.1 & 12.4 & 13.1 & 2.2 & 12.6 \\
\hline & MAG & 24.5 & 1.7 & 12.7 & 2.5 & 5.4 & 6.6 & 14.8 & 7.7 & 48.2 \\
\hline & FFA & 41.6 & 3.4 & 3.9 & 27.8 & 5.2 & 15.4 & 7.4 & 7.9 & 28.5 \\
\hline
\end{tabular}

3

$4 \quad *$ Major fatty acids identified.

$5 \quad$ Fatty acids composition of tuna oil at the $s n-2$ position before glycerolysis.

6 
1 Figure captions:

2 Fig. 1. Screening of organic solvents on MAG production with IM-AK. The reaction mixture contained $20 \mathrm{ml}$ of $30 \% \mathrm{w} / \mathrm{v}$ tuna oil in organic solvents and $1.78 \mathrm{~g}$ glycerol with 4 wt\% water. The amount of IM-AK used was $0.6 \mathrm{~g}$ (0.46 $\mathrm{U} / \mathrm{mg}$ ). The reaction was carried out at $300 \mathrm{rpm}$ and $45^{\circ} \mathrm{C}$ for $24 \mathrm{~h}$. PUFApolyunsaturated fatty acids, here meaning EPA and DHA and MAGmonoacylglycerol. The $\mathrm{Y}$-axis indicates the MAG weight content in the normalized lipid species profile analyzed by TLA-FID and PUFA weight content in the normalized fatty acid composition of the MAG fraction analyzed by GC.

Fig. 2. Effect of water content in glycerol on MAG production by IM-AK. The reaction mixture contained $20 \mathrm{ml}$ of $30 \% \mathrm{w} / \mathrm{v}$ tuna oil in MTBE and $1.78 \mathrm{~g}$ glycerol with various amounts of water content. The amount of IM-AK used was $0.6 \mathrm{~g}(0.46 \mathrm{U} / \mathrm{mg})$. The reaction was carried out at $300 \mathrm{rpm}$ and $45^{\circ} \mathrm{C}$ for 24 h. Abbreviations and notes to Y-axis see Figure 1.

Fig. 3. Effect of fish oil concentration on MAG production by IM-AK. The reaction mixture contained various amounts of tuna oil in $20 \mathrm{ml}$ of MTBE and $1.78 \mathrm{~g}$ glycerol with 4 wt\% water. The amount of IM-AK used was $0.6 \mathrm{~g}$ (0.46 $\mathrm{U} / \mathrm{mg}$ ). The reaction was carried out at $300 \mathrm{rpm}$ and $45^{\circ} \mathrm{C}$ for $24 \mathrm{~h}$. Abbreviations and notes to Y-axis see Figure 1.

Fig. 4. Effect of IM-AK loading on MAG production. The reaction mixture contained $20 \mathrm{ml}$ of $10 \% \mathrm{w} / \mathrm{v}$ tuna oil in MTBE and $1.78 \mathrm{~g}$ glycerol with $4 \mathrm{wt} \%$ water. The reaction was carried out at $300 \mathrm{rpm}$ and $45^{\circ} \mathrm{C}$ for $24 \mathrm{~h}$. Abbreviations and notes to $\mathrm{Y}$-axis see Figure 1. 
1 Fig. 5. Time course of glycerolysis by IM-AK in MTBE. The reaction mixture

2

6

7 contained $20 \mathrm{ml}$ of $10 \% \mathrm{w} / \mathrm{v}$ tuna oil in MTBE and $1.78 \mathrm{~g}$ glycerol with $4 \mathrm{wt} \%$ water. The amount of IM-AK was used $0.6 \mathrm{~g}(0.46 \mathrm{U} / \mathrm{mg})$. The reaction was carried out at $300 \mathrm{rpm}$ and $45^{\circ} \mathrm{C}$ for $24 \mathrm{~h}$. Abbreviations see Figure 1.

Fig. 6. Lineweaver-Burk plots for Lipase AK and IM-AK-catalyzed glycerolysis of tuna oil. 
Figure1

2

3

4

5

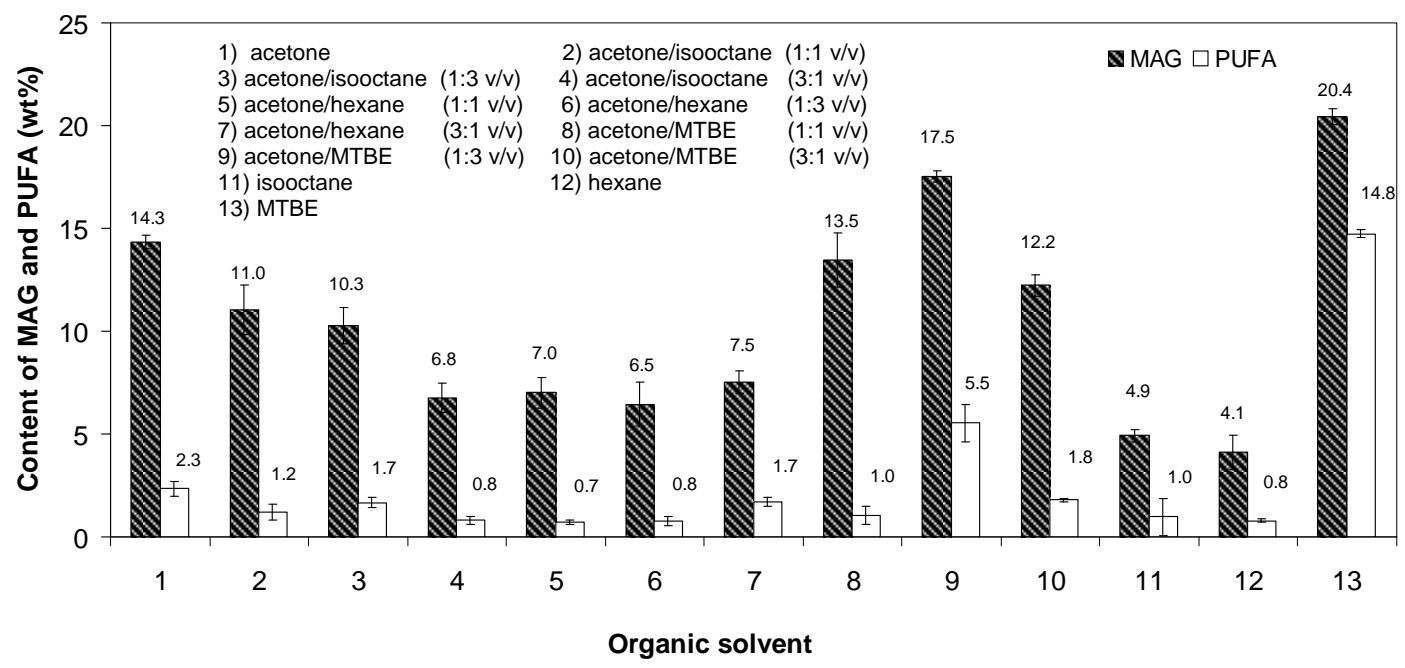

6
7

8

9

10

11

12

13

14

15

16

17

18

19

20

21

22 
Figure 2

2

3

4

5

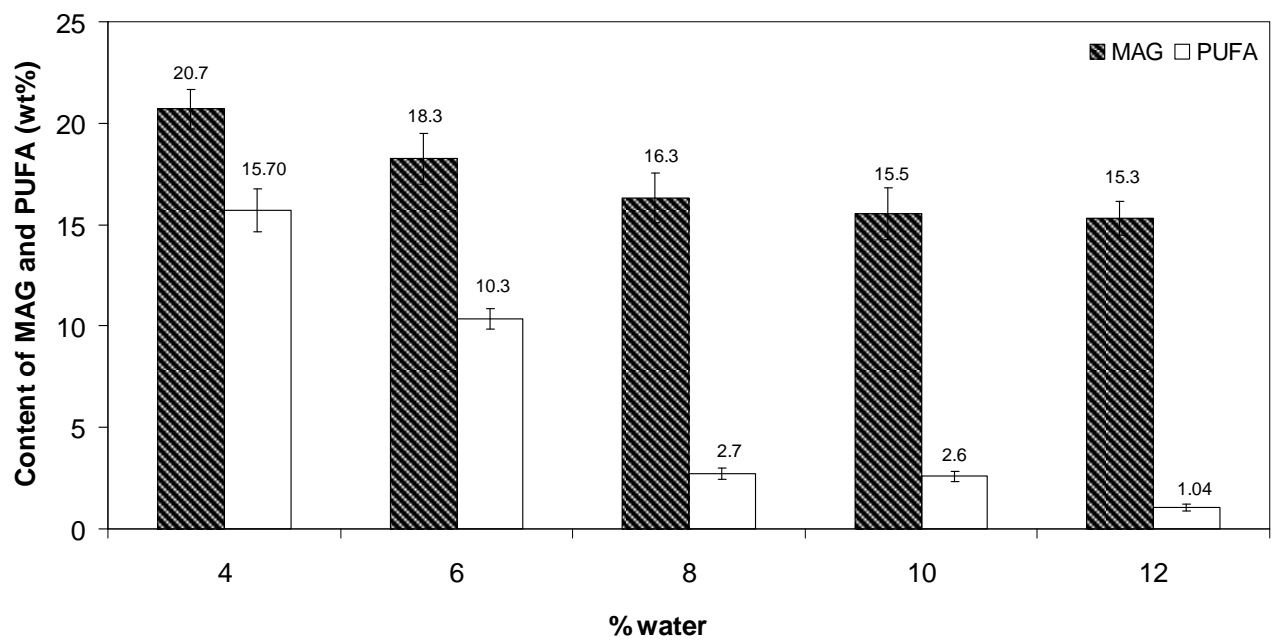

6

7

8

9

10

11

12

13

14

15

16

17

18

19 
Figure 3

2

3

4

5

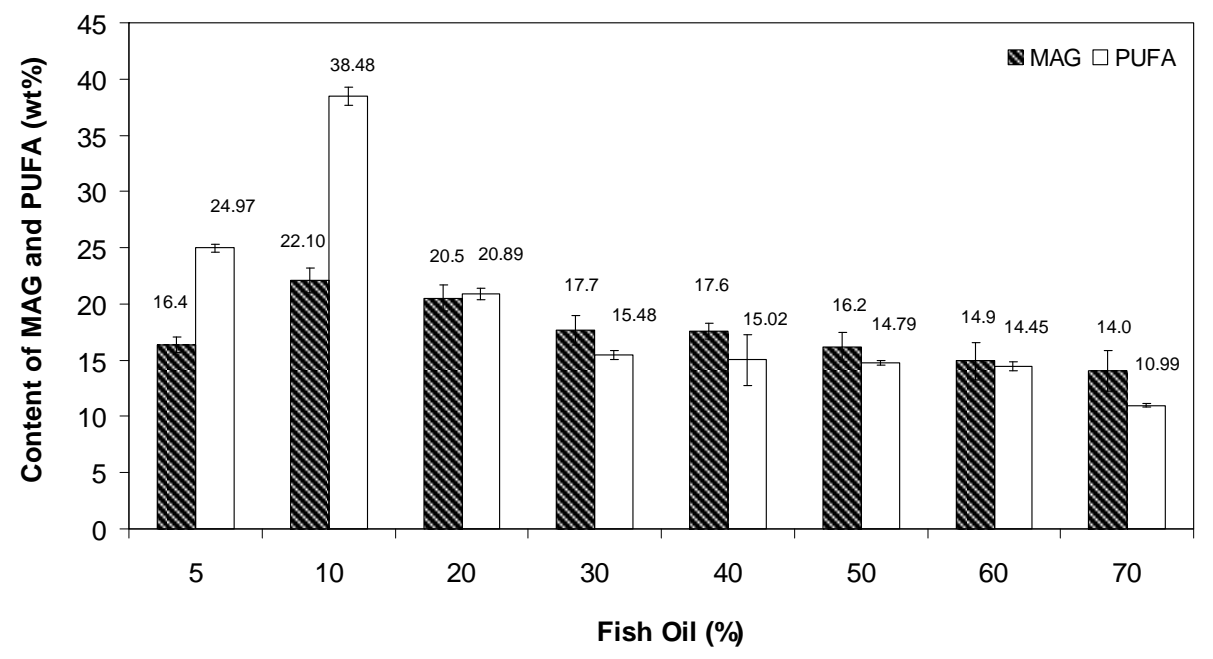

6

7

8

9

10

11

12

13

14

15

16

17

18 
$2 \quad$ Figure 4

3

4

5

6

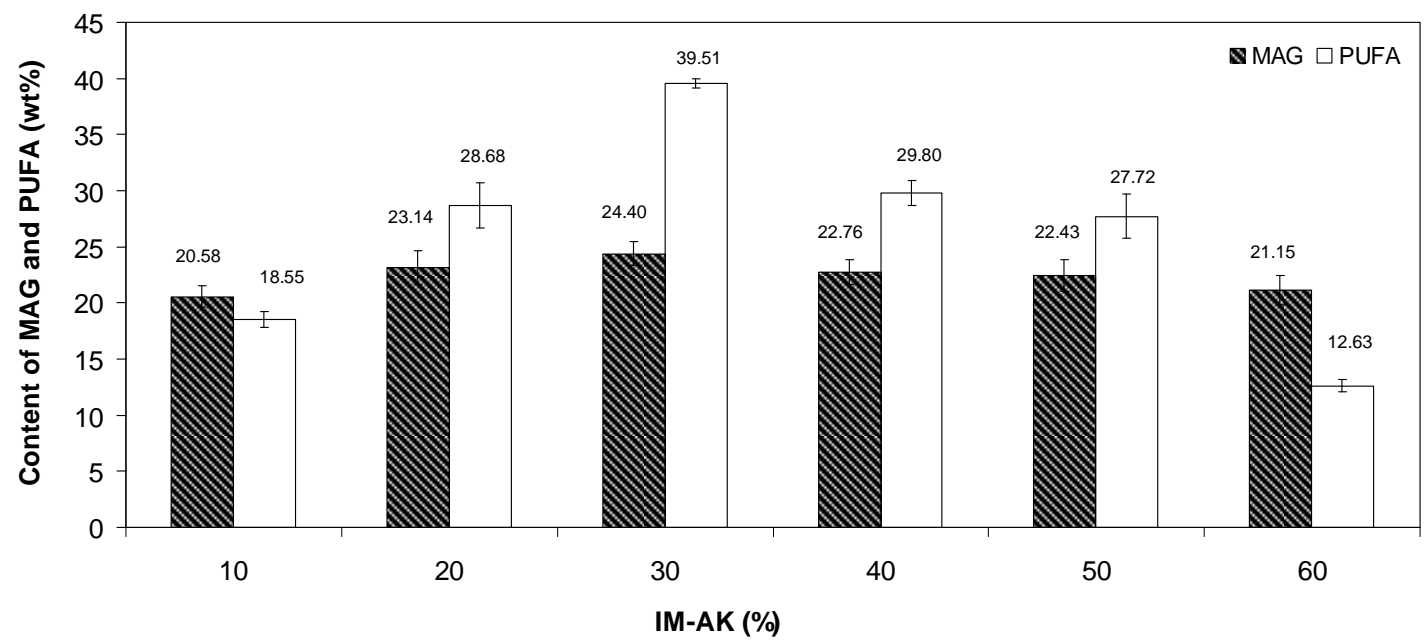

7

8

9

10

11

12

13

14

15

16

17

18

19 
1

2 Figure 5

3

4

5

6

7

8

9

10

11

12

13

14

15

16

17

18

19

20

21

22

23

24

25

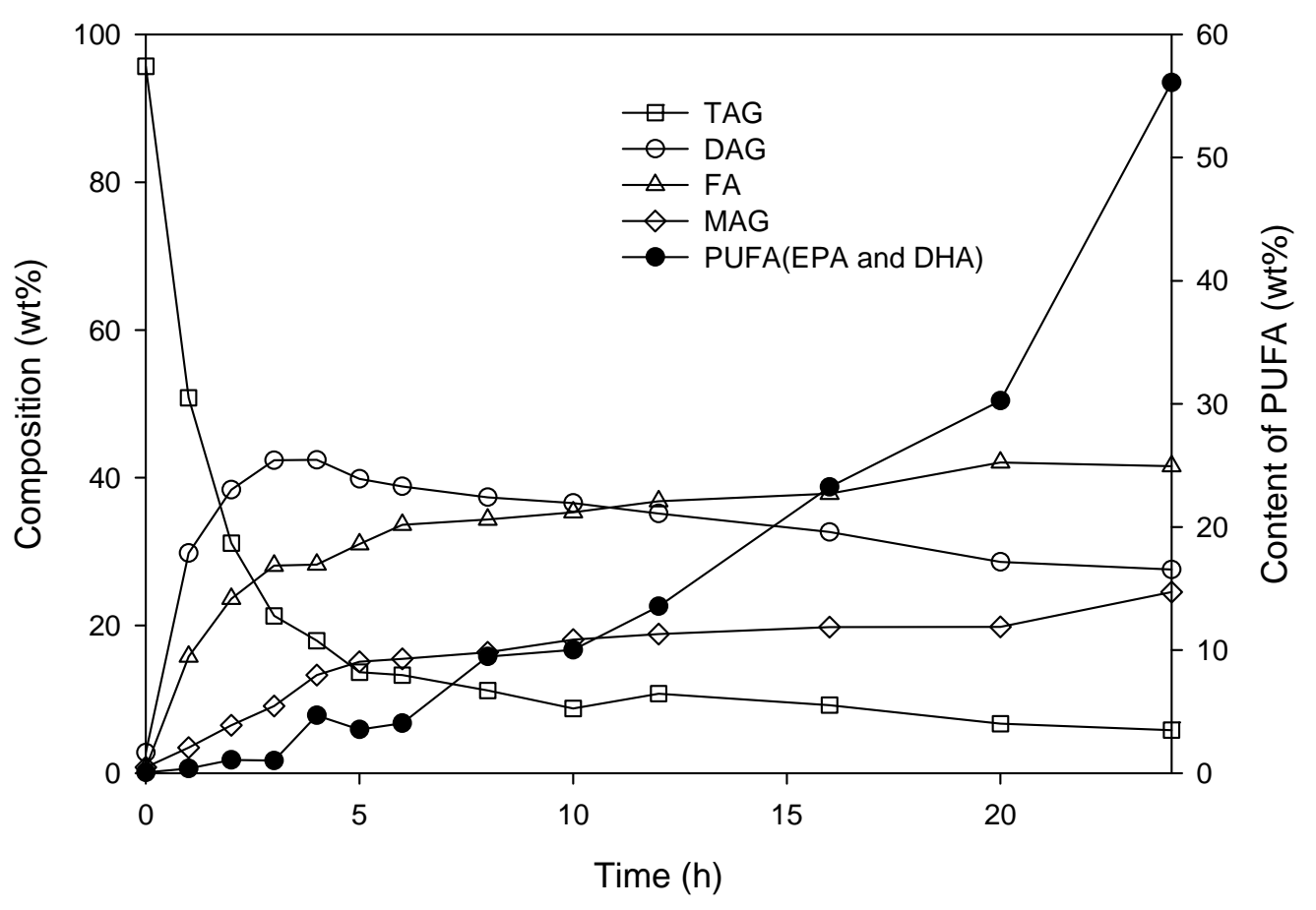


2 Figure 6

3

4

5

6

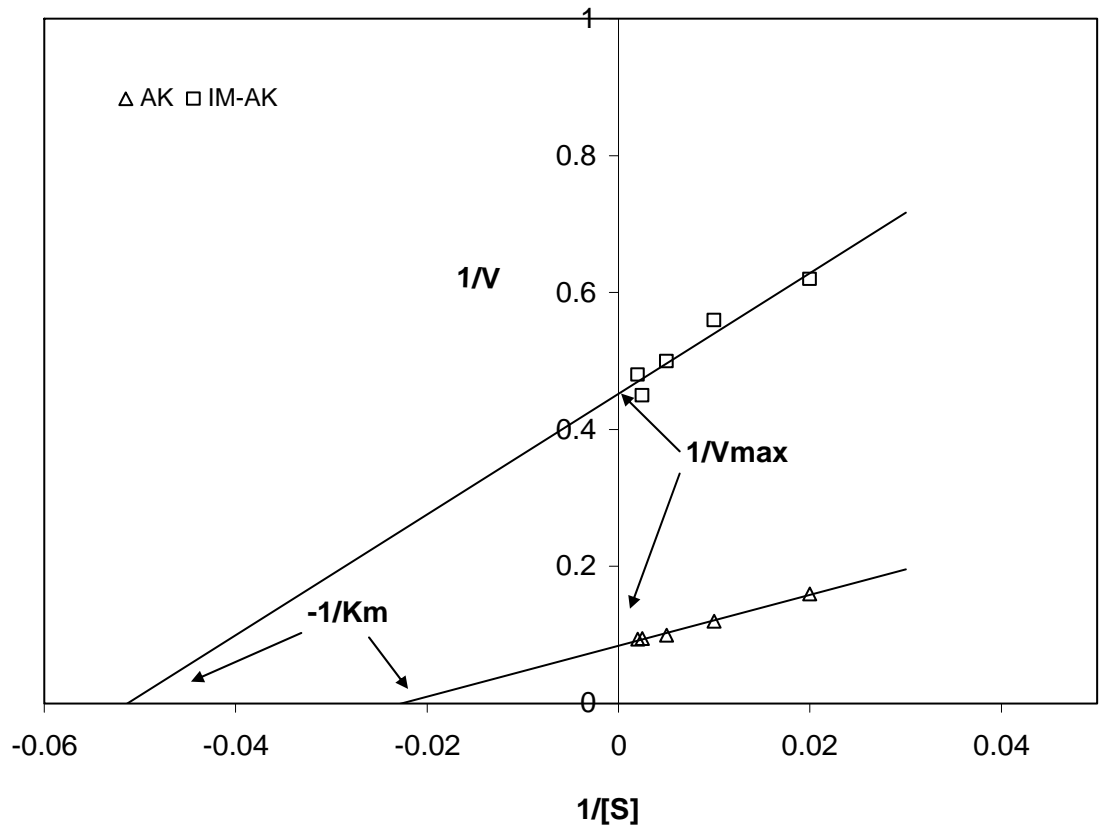

7

8

9

10

11

12

13

14

15

16 